\title{
ANALYSIS OF EFFICIENCY OF TECHNICAL AND FACTORS AFFECTING IN AROMATIC RICE FARMING IN THE SELUMA REGENCY
}

\author{
Maheran Mulyadi ${ }^{1)}$; Ketut Sukiyono ${ }^{2)}$; Sriyoto ${ }^{2)}$ \\ 1) Study Program of Agribusiness Magister Faculty of Agriculture, \\ University of Bengkulu \\ 2) Department of Agricultural Socio-Economics, Faculty of Agriculture, University of \\ Bengkulu \\ Email: ${ }^{1}$ ujang923@gmail.com; ${ }^{2}$ ksukiyono@unib.ac.id
}

\begin{abstract}
How to Cite :
Mulyadi, M., K Sukiyono, Sriyoto, 2020. Analysis Of Efficiency Of Technical And Factors Affecting In Aromatic Rice Farming In The Seluma Regency. Journal of Agri Socio-Economics and Business 3 (1): $1-12$
\end{abstract}

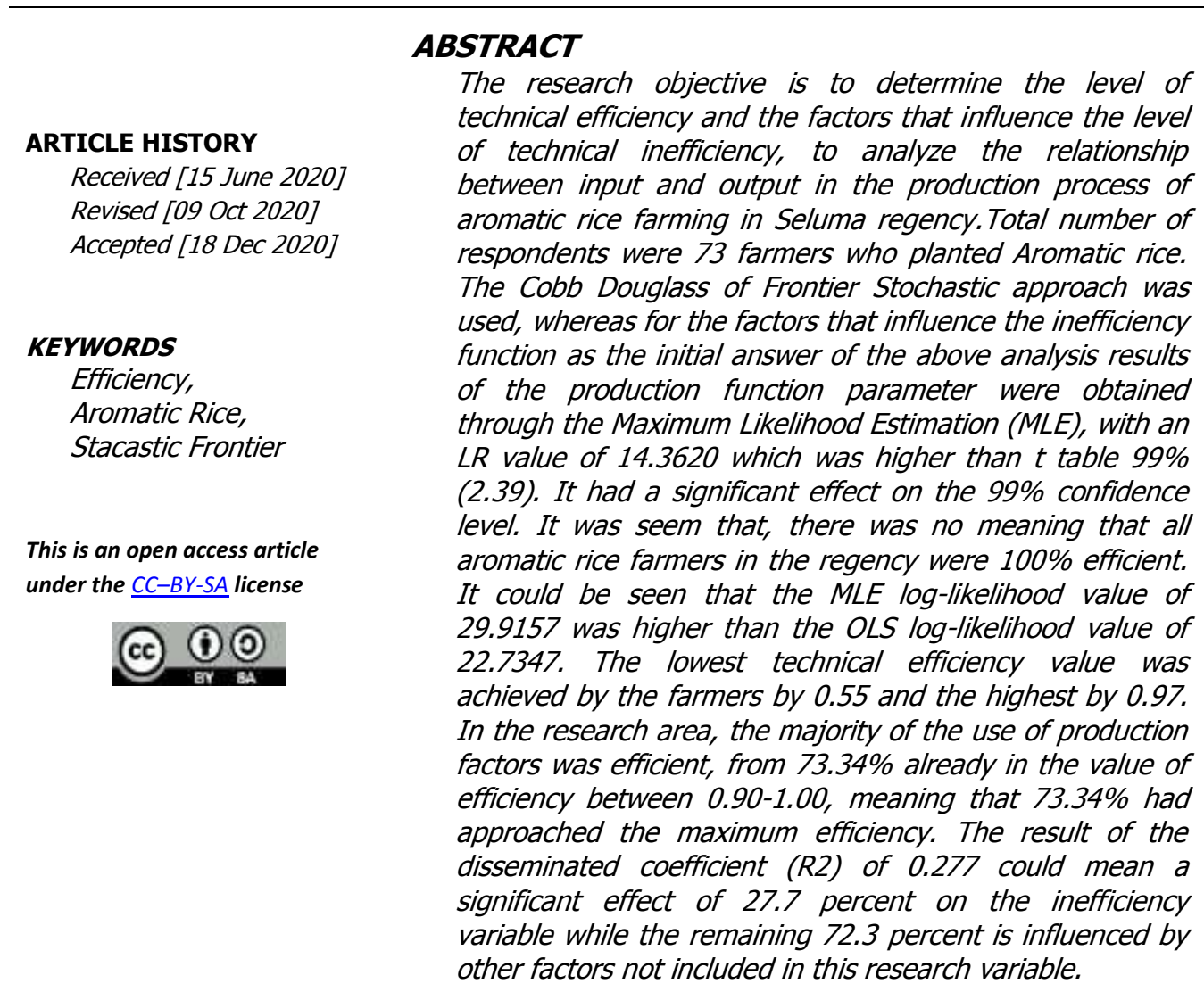




\section{INTRODUCTION}

Growing population growth makes the application of various technologies and agricultural innovations a necessity so that production can support high food demand The agricultural sector has an important role in economic development in Bengkulu Province. Based on the agroecosystem and land suitability, rice plants have great potential and opportunities to be developed in Seluma Regency. The harvested area of paddy in Seluma is $21,11 \mathrm{Ha}$ the productivity of paddy in Seluma only reaches $39.18 \mathrm{Ku}$ / $\mathrm{Ha}$ and the production of paddy is 82,727 tons (BPS, 2013).

Rice production in Seluma Regency decreased from 2010 to 2015. Rice production in 2013 reached 82.313 tons, and subsequently continued to decline every year until 2015 rice production was only 59,461 tons (BPS Bengkulu Province, 2015). Responding to the problem, the Seluma Regency Government innovated in increasing rice production under the guidance of the Bengkulu Province Agricultural Technology Study Center (BPATS). The rice varieties planted are aromatic rice. The availability of sufficient agricultural land makes this a potential for agricultural development in Seluma Regency.

According to the BBPADI(2015),to produce aromatic rice with higher levels of 2 Acetyl - 1 Pyroline (2-AP). Aromatic rice plants are recommended to be planted in cool climatic conditions and then harvested earlier than ordinary varieties. 2 Acetyl, 1 pyro line (2-AP) is an odorant that has a fragrance like pandan or popcorn. The fragrance of this pandanus fragrance is easily recognized from the aroma of rice, or even on rice that is in flower. This fragrant compound is naturally synthesized by aromatic rice plants, but not synthesized by non-aromatic rice plants. Some previous studies have shown that aromatic rice is non-aromatic rice that has mutations in certain chromosomes. These chromosome mutations cause the enzyme BADH2 (betaine aldeydrode dehydrogenase 2) in rice plants to become dysfunctional so that rice contains 2-AP compounds.

In every economic activity, an appropriate combination of inputs will be sought in order to obtain maximum output. In economics this is called efficiency. Soekartawi (2003) added that in economic triminology, efficiency can be divided into three, are technical efficiency, allocative efficiency and price as well as economic efficiency. Technical efficiency to cover the relationship between input and output. A company is technically efficiency if the production with the largest output used a combination of several inputs.

According to Sukiyono (2005),technical efficiency measures the extent to which a farmer converts inputs into outputs on economic levels and factors certain technology. This means that two farmers using the same amount and type of input and technology may produce different amounts of output. Besides, age, formal education, aromatic rice farming experience, number of family dependents, and land ownership status also affect technical efficiency. Achieving technical efficiency can be done if farmers know the production inputs that affect the farming undertaken by farmers, these production inputs must be allocated by farmers for their farming in order to get the maximum output. Based on the discussion above, this study aims to determine the level of technical efficiency of aromatic rice farming in Seluma District and to determine the factors that influence the level of technical inefficiency of aromatic rice farming in Seluma Regency. 


\section{RESEARCH METHODS}

\section{Determination of Research Locations}

This study was conducted in July - August 2018. Retrieval of the first planting season data in 2018. The method of determining the location was determined purposively in Seluma District with the consideration that Seluma Regency was the center of aromatic rice production in Bengkulu Province.

\section{Method of Collecting Data}

Data to be taken in this study are primary data and secondary data. Primary data is data obtained directly from respondents using in-depth interview techniques (dept interviews) using questionnaires or interview instruments. Secondary data can be obtained from pre-existing data (Arikunto, 2006). This data can be obtained from agencies or institutions that are closely related to research or obtained from the literature or literature then this data is tabulated and analyzed further.

\section{Methods for Determining Respondents}

The method of determining respondents in this study is the census method or total sampling. This method applies if the population is relatively small and easy to reach. It is expected that this sampling method tends to be closer to the real value and can minimize errors in population values (Husaini, et.at, 2008). Respondents in this study were all members of the population of aromatic rice farmers in Seluma Regency. Based on oral communication with the Department of Agriculture in Seluma District and the chairman of the Seluma District Contact Farmers Main Fishermen Organization. it was found that 73 farmers were planting aromatic rice. The distribution of aromatic rice farmers in Seluma Regency can be seen in Table 1.

Table 1 Number of farmers planting aromatic rice in Sintanur Varieties in Seluma Regency

\begin{tabular}{llc}
\hline No & \multicolumn{1}{c}{ Sub-District } & Number of Farmers \\
\hline 1 & Semidang Alas Maras & 9 \\
2 & Semidang Alas & 11 \\
3 & Kecamatan Ilir Talo & 5 \\
4 & Talo Induk & 9 \\
5 & Talo Kecil & 3 \\
6 & Seluma & 6 \\
7 & Seluma Selatan & 17 \\
8 & Sukaraja & 7 \\
9 & Kecamatan Lubuk Sandi & 4 \\
\hline & Total & 73 \\
\hline
\end{tabular}

Source: KTNA Seluma Regency, 2018

\section{Data Analysis Method}

To be able to analyze the factors that influence the level of technical efficiency of aromatic rice farming, the first thing to do is to measure the level of efficiency of each respondent at the study site. Therefore, to further simplify the analysis of the collected data, a model is used. This model is used to connect inputs with output in the 
production process. This case is the form of the production function is the Cobb Douglass production function of the Stochastic Frontier approach because 1) this functional form is commonly used in many empirical studies, especially farm research in developing countries, and 2) can be formed into the dual functions needed to calculate economic efficiency (Fauziyah, 2010). According Soekartawi (1994), production function form Cobb-Douglass functional equation, systematically is written as follows:

$$
\begin{aligned}
& Q=a X_{1}^{b_{1}} X_{2}^{b_{2}} X_{3}^{b_{3}} \ldots \ldots . X_{n}^{b_{n}} e^{u} \\
& =a \pi X_{i}^{b i} e^{u}
\end{aligned}
$$

If the Cobb-Douglas function is expressed by the relationship $Y$ and $X$ then: Notes:$$
Y=f(X 1, X 2 \ldots, X i, \ldots, X n)
$$

$$
\begin{array}{llll}
\mathrm{Q} & =\text { Variable explained } & \mathrm{A}, \mathrm{b} & =\text { Expected magnitude } \\
\mathrm{X} & =\text { Variable that explains } & \mathrm{u} & =\text { Error (disturbance term) } \\
\mathrm{e} & =\text { Natural logarithm } & &
\end{array}
$$

\section{Empirical Model}

This model is further transformed in a linear, Cobb-Douglas stochastic frontier production function for aromatic rice farming can be as follows:

$\ln Q_{t}=\beta_{0}+\beta_{1}$ lnArea $+\beta_{2} \ln B n i+\beta_{3} \operatorname{lnKndg}+\beta_{4}$ lnPnska $+\beta_{5}$ lnfungi $+\beta_{6} \operatorname{lninsek}++\beta_{7} \operatorname{lnLabor}+\left(V_{i}-U_{i}\right)$

Notes:

$$
\begin{array}{ll}
\beta_{0} & =\text { Intercept } \\
\beta^{1} \ldots \beta^{7} & =\text { Coefficient Regression Coefficient production factors } \\
\mathrm{Vi} & =\text { Model random error } \\
\mathrm{Ui} & =\text { Random variable representing the inefficiency of technical }
\end{array}
$$

While the measurement of the efficiency or inefficiency of aromatic rice farming technique is assumed by using the equation formulated by Battese and Coelli (1988) and Kumbhakar and Lovell (2000) cited by Sukiyono (2005) as follows:

$$
T E_{i}=\frac{Q_{i}}{Q i}=\frac{\exp \left(x_{i} \beta+V_{i}-u_{i}\right)}{\exp \left(x_{i} \beta+V_{i}\right)}=\exp (-\mathrm{ui})
$$

Notes:

TEi = Technical efficiency that can be achieved by the i-th farmer

Qi = actual output of aromatic rice farming $(\mathrm{kg} / \mathrm{ha})$

Qi* = potential output of aromatic rice farming $(\mathrm{kg} / \mathrm{ha})$

$U_{i} \quad=$ one-side error term $\left(v_{i} \geq 0\right)$ or random variable

To determine the factors that influence technical efficiency, the econometric model cited from Sukiyono \& Sriyoto (2010)is used as follows: Notes:

$$
\text { eff } f_{i}=\alpha_{0}+\alpha_{1} E d u_{i}+\alpha_{2} E_{x p}+\alpha_{3} E x t_{i}+\alpha_{4} A g e_{i}+\alpha_{5} S k l_{i}+u_{i}
$$

eff $f_{i}=$ technical efficiency

Age $=$ Farmer Age (Year)

Edu = Length of Formal Education

(Year)
Exp $=$ Farming Experience (Year)

$\mathrm{Skl}=$ Land Ownership Status 
The results of processing the FRONTIER 4.1c program according to Aignner et al. (1979), Jondrow et al. (1982) or Greene (1993) inCoelli, et. al, (1998), will provide an estimated value of variance in the form of parameters as follows:

$$
\begin{aligned}
& \sigma^{2}=\sigma_{v}^{2}+\sigma_{u}^{2} \\
& Y=\frac{\sigma_{u}^{2}}{\sigma_{v}^{2}}
\end{aligned}
$$

The parameter of this variance is used to find the value of $y$ so that $0<y<1$. The parameter value $y$ is a contribution of technical efficiency in the total residual effect. To partially test the regression coefficient, a t-test is performed, at a certain significance level. In the hypothesis test the factors that influence inefficiency function as an initial answer from the above analysis.

\section{RESULTS AND DISCUSSION}

\section{Characteristics of Aromatic Rice Farmers}

Characteristics are data or properties of the objects observed in the study. The purpose of the characteristics is to determine the condition and condition of the object to be observed as presented in Table 2.

The average experience of farming in Aromatic rice farmers is 18.84. The biggest percentage is in the range of $13-23$ years or $47.95 \%$ as many as 35 people than the range of $<13$ years is 21 people or $28.77 \%$ while the smallest range is $>23$ years as many as 17 people or $23.29 \%$. The experience of farming is referred to as the experience of rice farming in addition to aromatic rice farming which is usually used as experience in helping the management of aromatic rice farming that they are currently trying. This means that the experience of rice farming in addition to aromatic rice they have done so far has been very petrified in optimizing the production factors of aromatic rice cultivation because cultivation is almost the same as rice cultivation in general, this experience ranges from 13 years to 23 years or $47.95 \%$.

The average of rice farming experience is 2.98 years. The highest percentage had 2 years of rice farming experience, $36.99 \%$ while the lowest farming experience was in the range of 5 years, $2.74 \%$. This shows that most farmers have a relatively new experience in rice farming, so this is one of the indications that illustrates that the farmers have less experience in the field of aromatic rice farming so that it can affect the productivity of Aromatic rice farming.

The average area of aromatic rice farming in Seluma Regency is $0.59 \mathrm{Ha}$. The largest percentage of aromatic rice farming areas is $61.64 \%$ with a range of 0.48 to 0.7 Ha with 45 people, followed by a range between $<0.48$ Ha with 19 people or around $26.03 \%$. The range of aromatic rice farmers' smallest land area is $>0,7 \mathrm{Ha}$ with an area of 9 people or around $12.33 \%$. This means that the most extensive use of land area cultivated by aromatic rice farmers in Seluma Regency is the most cultivated area ranging from 0.48 to $0.7 \mathrm{Ha}$ or $61.64 \%$ less than 1 hectare of land used by farmers to grow aromatic rice whether it is their land or even the land that they lease while the farmers who own their land number 40 people with a percentage of $54.79 \%$. Farmers with leased land status amounted to 33 people with a percentage of $45.21 \%$. owning their land, only some rent land. This means that farmers in the study area can still rely on the agricultural sector to meet the needs of their families through the income they receive from the farming they work on. 
Table 2 Characteristics of Aromatic Rice Farmers in Seluma Regency

\begin{tabular}{|c|c|c|c|c|}
\hline No & Caracteristic & Amount (Person) & $\begin{array}{c}\text { Percentage } \\
(\%)\end{array}$ & Average \\
\hline \multirow[t]{4}{*}{1} & Age (years) & & & \\
\hline & $<37$ & 21 & 28,77 & 42,30 \\
\hline & $37-46$ & 38 & 52,05 & \\
\hline & $>46$ & 14 & 19,18 & \\
\hline \multirow[t]{4}{*}{2} & Family Dependent (person) & & & \\
\hline & $<3$ & 49 & 67,12 & 27.97 \\
\hline & $3-4$ & 24 & 32,88 & \\
\hline & $>4$ & 0 & 0 & \\
\hline \multirow[t]{4}{*}{3} & Formal Education (years) & & & \\
\hline & 6 & 21 & 28,77 & 9,45 \\
\hline & 9 & 22 & 30,14 & \\
\hline & 12 & 30 & 41,07 & \\
\hline \multirow[t]{5}{*}{4} & Non Formal Education & & & \\
\hline & 0 (never) & 57 & 78,08 & 0,45 \\
\hline & 1 (during 1 year) & 7 & 9,59 & \\
\hline & 2 (during 2 years) & 1 & 1,37 & \\
\hline & 3 (during3years) & 8 & 10,96 & \\
\hline \multirow[t]{4}{*}{5} & Experience of farming (years) & & & \\
\hline & $<13$ & 21 & 28,77 & 18,84 \\
\hline & $13-23$ & 35 & 47,95 & \\
\hline & $>23$ & 17 & 23,29 & \\
\hline \multirow[t]{6}{*}{6} & Experience of rice farming & & & \\
\hline & (years) & 27 & 36,99 & 2,98 \\
\hline & 2 & 22 & 30,14 & \\
\hline & 3 & 23 & 31,51 & \\
\hline & 4 & 2 & 2,74 & \\
\hline & 5 & & & \\
\hline \multirow[t]{4}{*}{7} & Area of rice farming $(\mathrm{Ha})$ & & & \\
\hline & $<0,25$ & 18 & 28,87 & 0,55 \\
\hline & $0,48-0,7$ & 44 & 65,67 & \\
\hline & $>0,7$ & 5 & 2,46 & \\
\hline \multirow[t]{3}{*}{8} & Land Ownership Status & & & \\
\hline & One's own & 36 & 54,79 & \\
\hline & Rent & 37 & 45,21 & \\
\hline
\end{tabular}

Source: Primary Data, 2018

\section{Production Input Used for Aromatic Rice Farming}

Input Use of production inputs in farming activities is very important because it will affect the products produced. Production inputs analyzed in this study include the area of land, seeds, manure, ponska fertilizer, fungicides, insecticides, and labor to be presented in Table 3.

The area of farming land is often taken into consideration by farmers in making decisions to accept innovation. Usually, farmers who have large arable farming will dare to take risks compared to farmers who have smaller arable land. But generally, farmers feel afraid if the costs incurred to buy production facilities are greater than the harvest they receive. The average area of aromatic rice land managed by farmers is 
0.55 ha. The seeds used in aromatic rice farming will affect production to be achieved.The seeds planted by aromatic rice farmers are sintanur varieties certified with an average seed use of $17.14 \mathrm{~kg}$. Besides seeds, farmers also need other inputs in the form of 1.74 tons of manure, $111.58 \mathrm{~kg}$ of Ponska fertilizer, 0.66 liters of fungicide, 2 liters of insecticide. The use of pesticides by farmers differs depending on the disease, price, and habits of the farmer. Furthermore, aromatic rice farming requires a workforce of $89.53 \mathrm{HKSP} / \mathrm{ha}$.

Table 3 Average Usage of Aromatic Rice Production Input in Seluma Regency

\begin{tabular}{llrrr}
\hline No & \multicolumn{1}{c}{ Description } & \multicolumn{1}{c}{ Average } & \multicolumn{1}{c}{ Minimum } & \multicolumn{1}{c}{ Maximum } \\
\hline 1 & Area of land (ha) & 0,56 & 0,25 & 1,7 \\
2 & Seeds (kg) & 17,14 & 10 & 40 \\
3 & Manure (ton) & 1,74 & 0,5 & 4,5 \\
4 & Ponska (kg) & 111,85 & 50 & 300 \\
5 & Fungicides (liter) & 0,66 & 0 & 4,5 \\
6 & Insecticides (liter) & 2,00 & 0,25 & 3,5 \\
7 & Labor (HKSP) & 89,53 & 35 & 235 \\
\hline
\end{tabular}

Source: Primary Data, 2018

\section{Analysis of Stochastic Frontier Production Function Aromatic Rice}

\section{Production Function Aromatic Rice}

Production Function The model used to estimate aromatic rice production function is the stochastic frontier Cobb-Douglass function model. This production function model uses the Maximum Likelihood Estimation (MLE) estimator method which is carried out through two stages. The first stage uses the OLS method (ordinary least square) to illustrate the average performance of aromatic rice production can be seen in Table 4.

Table 4 Estimation Results of OLS Stochastic Frontier Production Function in Aromatic Rice Farming in Seluma Regency

\begin{tabular}{lrrr}
\hline \multicolumn{1}{c}{ Variable } & Coefficient & StandardError (Se) & \multicolumn{1}{c}{ T-ratio } \\
\hline Beta 0 (constan) & $-0,9807$ & 0,5685 & $-1,725$ \\
Beta 1 (area of land) & 0,2090 & 0,0960 & $2,1771^{* *}$ \\
Beta 2 (seeds) & 0,2059 & 0,1151 & $1,7886^{* *}$ \\
Beta 3 (manure) & 0,1736 & 0,0676 & $2,5674^{* *}$ \\
Beta 4 (ponska) & 0,1866 & 0,0901 & $2,0703^{* *}$ \\
Beta 5 (fungicide) & 0,0072 & 0,0031 & 0,2317 \\
Beta 6 (insekticide) & 0,0116 & 0,0116 & 0,9980 \\
Beta 7 (labor) & 0,1765 & 0,1048 & 1,6828 \\
\hline Gamma (Y) & $\mathbf{0 , 8 2 0}$ & & \\
Sigma squared & $\mathbf{0 , 0 3 5 2}$ & & \\
Log likelihood function OLS & $\mathbf{2 2 , 7 3 4 7}$ & & \\
\hline Tabel (a $=99 \%)$ & 2,39 & & \\
Tabel (a $=95 \%)$ & 1,67 & & \\
Tabel (a $=90 \%)$ & 1,29 & & \\
\hline
\end{tabular}

Source: Processed Data by frontier 4.1c, 2018

Notes: $* * \quad=$ very significant 
The results of the estimation by the OLS method are presented in Table 4. The gamma $(Y)$ value obtained was 0.8200 . These results indicate that $82 \%$ of the variation of aromatic rice farming in Seluma Regency is caused by technical efficiency while the remaining $18 \%$ is influenced by the effects of stochastic, so many aromatic rice farming is not caused by inefficiency variables but the effect of random errors that are not included in the model. Table 4 shows that land area, number of seedlings, manure and ponska fertilizer as factors affecting aromatic rice farming in Seluma Regency, have a positive and significant influence on production factors with a $95 \%$ confidence level. This result is proven by $\mathrm{t}$-ratio greater than $\mathrm{t}$-table on area ofland variable that is equal to $2.177>1.67$, the variable number of seeds is $1.78>1.67$, manure variable is $2.56>$ 1.67 , variable Ponska fertilizer is $2.070>1.67$ and labor variable is $1.682>1.67$. While the other variables do not have a positive influence on the aromatic rice farming factor in Seluma Regency.

The MLE method is used to describe the relationship between maximum production (output) that can be achieved at the level of use of existing production factors (inputs), as well as to see the level of technical efficiency and technical inefficiencies of Aromatic rice production in Seluma Regency. For more details about the results of the estimation using the MLE stochastic frontier function model in Table 5.

Table 5 Estimation Results of MLE Stochastic Frontier Production Function in Aromatic Rice Farming in Seluma Regency

\begin{tabular}{lrrr}
\hline \multicolumn{1}{c}{ Variable } & Coefficient & StandardError (Se) & \multicolumn{1}{c}{ T-ratio } \\
\hline Beta 0 (constan) & $-1,0328$ & 0,4878 & $-2,1173$ \\
Beta 1 (area of land) & 0,1613 & 0,0730 & $2,2083^{* *}$ \\
Beta 2 (seeds) & 0,1710 & 0,0996 & $1,7171^{* *}$ \\
Beta 3 (manure) & 0,1804 & 0,0581 & $3,1053^{* * *}$ \\
Beta 4 (ponska) & 0,1663 & 0,0713 & $2,3327^{* *}$ \\
Beta 5 (fungicide) & 0,0023 & 0,0027 & 0,8814 \\
Beta 6 (insekticide) & 0,0115 & 0,0010 & 1,1523 \\
Beta 7 (labor) & 0,2531 & 0,0960 & 0,9910 \\
\hline Sigma squared & 0,1738 & 0,1753 & 9,2461 \\
Gamma ( $($ ) & 0,9090 & & \\
Log likelihood function MLE & 29,9157 & & \\
LR test of the one-side error & 14,3620 & & \\
Mean efficiency & 0,9005 & & \\
\hline Tabel (a = 99\%) & 2,39 & & \\
Tabel ( $\mathrm{a}=95 \%)$ & 1,67 & & \\
Tabel ( $\mathrm{a}=90 \%)$ & 1,29 & & \\
\hline
\end{tabular}

Source: Processed Data by frontier 4.1c, 2018

Notes:

$* * * \quad=$ significant

$* * \quad=$ very significant

The estimation results using the MLE method in Table 5 show a gamma value ( $y$ ) that is greater than the OLS method that is equal to 0.9090 . This means that there is a factor between the actual Aromatic rice farming and maximum production caused more by the effects of technical inefficiency, not other factors not included in the model. The 
gamma value $(y)$ of 0.9090 indicates that the variation in the value of the error is due to the high technical inefficiency component that is equal to $90 \%$. The measurement and gamma value $(y)$ which are close to 1 indicate that the error term only comes from the inefficiency. If it is close to zero, it is interpreted that all error terms are a result of noise (vi) such as weather, pests, and so on, not due to inefficiency.

To answer the proposed hypothesis whether all aromatic rice farmers do their farming efficiently, it can be seen by the LR value. LR value of 14.3620 is greater than t table $99 \%$ (2.39) significantly affected the level of confidence of $99 \%$. Judging from the value there is no o or which means that all aromatic rice farmers in the Regency are $100 \%$ efficient. The estimation result of the MLE log-likelihood value of 29.9157 is greater than the OLS log-likelihood value of 22.7347 this means that the production function using the MLE method can be said to be good. Also, the alleged results by using the MLE method on average production factor variables have a positive effect on the increase in aromatic rice farming production in Seluma Regency.

\section{Technical Efficiency Levels on Aromatic rice farming}

Technical efficiency is analyzed simultaneously using the stocastic frontier production function model to get the maximum output from the use of inputs. The level of technical efficiency of each factor influencing the production of aromatic rice farming in Seluma Regency. The distribution of technical efficiency of aromatic rise farming in Seluma Regency is shown in Tabel 6.

Table 6 Farming Distribution Based on Efficiency Level in Seluma Regency

\begin{tabular}{lrrr}
\hline & Efisiensi teknis & Jumlah & Persentase(\%) \\
\hline & $0,30-0,69$ & 4 & 5,48 \\
& $0,70-0,79$ & 3 & 4,11 \\
& $0,80-0,89$ & 11 & 15,07 \\
& $0,90-1,00$ & 55 & 73,34 \\
\hline Rata-rata & & 0,90 & \\
Minimun & & 0,55 & \\
Maksimum & & 0,97 & \\
\hline
\end{tabular}

Source: Processed Data, 2018

In the study area, the majority use of production factors is efficient. This is evident from $73.34 \%$ of farmers who are in an efficient value between $0.90-1.00$, meaning that $73.34 \%$ of farmers have approached maximum efficiency. This means that the average production is achieved by $90 \%$ of the frontier and can still be added by $10 \%$ of production inputs to get the maximum results that can be achieved through the best management of the system. This is supported by research conducted byHasan et. al (2016). The results from the inefficiency model are estimated to indicate that land size, age, education, training, and credit facilities are significant factors that are negatively related to the technical inefficiencies of aromatic rice production.

\section{Factors Influencing the Performance of Technical Inefficiencies}

To see the value of the achievement of technical inefficiencies and the factors of production that affect the inefficiency of aromatic rice farming, the SPSS program is used with the results of estimating the analysis of the factors affecting the level of performance of technical inefficiencies in Aromatic rice farming presented in Table 6. It shows that value of $\mathrm{R}^{2}$ has a value of 0.277 which means that overall the independent 
variables namely age (age), experience (exp), education (Edu) number of families (Agk) and land status (SKL) can explain changes in the dependent variable namely the level of technical inefficiency by $27,7 \%$. While the remaining $72.3 \%$ is explained by other factors not included in the model.

Table 7 Estimation Results of Inefficiency Level in Aromatic Rice Farming in Seluma Regency

\begin{tabular}{lrrr}
\hline \multicolumn{1}{c}{ Estimator } & coefficient & Standard error (Se) & \multicolumn{1}{c}{ T-ratio } \\
\hline Constant & 0,205 & 0,105 & 1,960 \\
Age & $-0,001$ & 0,001 & $-0,677 \mathrm{~ns}$ \\
Experience & $-0,031$ & 0,010 & $-3,049 \mathrm{~ns}$ \\
Education & $-0,005$ & 0,004 & $-1,046 \mathrm{~ns}$ \\
Number of families & 0,027 & 0,009 & $3,115^{* * *}$ \\
Land status & $-0,045$ & 0,017 & $-2,567 \mathrm{~ns}$ \\
\hline $\mathrm{R}^{2}$ & 27,7 & & \\
F-ratio & $5,141 * * *$ & & \\
T-Table (99\%) & 2,383 & & \\
F-table (99\%) & 3,059 & & \\
Responden & 73 & & \\
\hline
\end{tabular}

Source: Processed Data, 2018

Notes:

$* * * \quad=$ significant at a $1 \%$

Ns $=$ Not significant

Tabel 7 shows that the $F$ value is 5.141 . When compared with the F-table value, then the F-ratio is greater than the $\mathrm{F}$ table that is 5.141> 3.059. This means that this value is significant at the error level (a) of $a=0.01$ or has a confidence level of $99 \%$. This means that all independent variables together have a significant effect on technical inefficiency. Whereas the test used for individual licensing variables can be explained as follows:

\section{Age}

T-value of the age is -0.6677 and a regression coefficient of -0.001 . When compared with a table of 1,264 , then t-ratio<t-table. This means that $\mathrm{H} 0$ is accepted, which means age does not affect technical inefficiency. In the research of Isyanto (2011),Yoko, et. al (2014), explained that age levels harmed technical inefficiencies. This means that the older the farmer, the higher the level of technical inefficiency.

\section{Experience}

T-test on experience generated $t$ value of -3.049 and a regression coefficient of -0.031 . When compared with t-table of 1.264 , t-ratio $<\mathrm{t}$ - table. This means that $\mathrm{Ho}$ is accepted, which means the experience does not affect technical inefficiency. In contrast to the research Suharyanto, et.al (2015), Heni \& Ketut (2018) in this study the experience affected the technical inefficiency although it was negative. These conditions indicate that if the experience added by $10 \%$ will reduce inefficiency by 0.031 ten percent, the more experienced the farmer, the more efficient his farming or the lower the inefficiency. 


\section{Educational}

From the results of the t-test on Educational generated a t-ratio of -1.046 and a negative coefficient value of -0.005 . When compared with the t-table of 1.264 , then $\mathrm{t}$ ratio $<$ t-table. This means that $\mathrm{Ho}$ is accepted, which means the educational does not affect technical inefficiency. Heni \& Ketut (2018), states that education increases the ability of farmers to find, obtain, and interpret useful information about production inputs. However, in the research location, many people took tertiary education, after succeeding they preferred to work outside the agricultural sector.

\section{Number of families}

Statistic test to the variable number of families is indicates t-value of it is 3.115 and a positive coefficient value of 0.027 . When compared with t-table at a $99 \%$ confidence level of 2.383, then t-ratio $>\mathrm{t}$-table. This means that $\mathrm{H} 1$ is accepted,which means the variable number of families significantly influences technical inefficiency. By having a positive value coefficient $(0.027)$ which means the more the number of household members, the more inefficient the farming business. This is because at the research location families who have family members who are dependents but cannot help farming activities because they are still pursuing education.

\section{Land Status}

Land Status is the Land Ownership Status by farmers that are measured by a dummy variable with the statement 1 = "self-owned land" and 0 = "leased land". Estimation results show that the Land Status Variable with a t-ratio of -2.567 and a negative coefficient value of -0.045 . When compared with the t-table of 1.264 , then $t-$ ratio $<$ t-table. This means that $\mathrm{Ho}$ is accepted, which means that the Land Status variable does not affect technical inefficiency. This condition is consistent with research conducted by Kusnadi, et. al (2013), Tinaprilla, et.al (2013)which shows that ownership status does not have a significant effect with a negative sign on technical inefficiency. This is since each of the owner's farmers and their smallholders have an interest in the success of their farming.

\section{CONCLUSIONS AND POLICY IMPLICATIONS}

\section{Conclusions}

1. a. Aromatic rice farmers in Seluma District have done their farming efficiently.

b. Aromatic rice production in Seluma Regency is significantly affected by land use, seeds, manure, phonska fertilizer, insecticides, fungicides, and labor, which has been technically efficient with an average performance value of 0.9005 technical efficiencies.

2. The number of families (Agk) significantly influences the inefficiencies of aromatic rice farming in Seluma District, while the experience (Exp), Land Ownership Status (SLC), age (Age), and Education (Edu) do not affect. 


\section{Recommendations}

In an effort to increase the yield of aromatic rice production in Seluma District, farmers need to make efforts to expand their farming. This is based on the results of research showing that factors of production such as land area, seeds, manure and ponska fertilizer affect the amount of aromatic rice production. Furthermore, in the long term farmers need to do intensive business by developing the farming technology used. In order to achieve these two objectives, the government needs to play a role in increasing the role of extension workers to provide guidance and assistance to farmers, especially related to obstacles faced by farmers.

\section{REFERENCES}

Arikunto. (2006). Prosedur Penelitian. Jakarta: Reneka Cipta.

BBPADI. (2015). Usahatani Padi Aromatik. Dipetik November 11, 2018, dari Balai Besar Penelitian Tanaman Padi: http://bbpadi.litbang.pertanian.go.id

BPS. (2013). Bengkulu dalam Angka 2012. Bengkulu: Badan Pusat Statistik Provinsi Bengkulu.

Badan Pusat Statistik. (2015). Bengkulu Dalam Angka 2014. Bengkulu: BPS Provinsi Bengkulu.

Coelli, T. J., R. D., O. D., \& B. G. (1998). An Introduction to Efficiency and Productivity Analysis. Boston: Kluwes Academic Publishers.

Hasan, M., E. H., \& A. G. (2016). Technical Efficiency of Boro Rice Production in Jhenaidah District of Bangladesh: A Stochastic Frontier Approach. International Journal of Agricultural Economics 1 (4) : 103-107.

Heni, S. P., \& Ketut, I. (2018). Faktor Produksi dan Efisiensi Teknis Usahatani Padi Sawah pada Sistem Tanam Jajar Legowo dan Sistem Tegel di Desa Sidondo Sulawesi Tengah. UNS 2 (1).

Husaini. U, A.P. Setiady. 2008. Metodologi Penelitian Sosial. Jakarta: Bumi Aksara

Isyanto, A. Y. 2011. Faktor-faktor yang Mempengaruhi Inefisiensi Teknik pada Usahatani Padi di Kabupaten Ciamis. Cakrawala Galuh 5(1): 31-40

Kusnadi, N., N. T., S. H., \& Adreng. (2013). Analisis Efisiensi Usahatani Padi di Jawa Barat Indonesia. Jurnal Agribisnis 7 (1): 15-34.

Soekartawi. (1994). Teori Ekonomi Produksi dengan Pokok Bahasan Analisis Fungsi Cobb-Douglas. Jakarta: Rajawali Pers.

Suharyanto, J.H Mulyo, D.H Darwanto, S. Widodo. 2015. Analisis Produksi dan Efisiensi Pengelolaan Tanaman Terpadu Padi Sawah di Provinsi Bali. Jurnal Penelitian Pertanian Tanaman Pangan 34 (2): 131-144

Sukiyono, K. (2005). Faktor Penentu Tingkat Efisiensi Teknik Usahatani Gabai Merah di Kecamatan Selupu Rejang Kabupaten Rejang Lebong. Jurnal Agro Ekonomi 23 (2) : 176-190.

Sukiyono, K., \& Sriyoto. (2010). Analisis Efisiensi Teknik Usahatani Padi pada Dua Tipologi Lahan yang Berbeda di Provinsi Bengkulu. Jurnal SOCA 10 (1) :3339.

Tinaprilla, N., N. Kusnadi, B. Sanim, D.B. Hakim. 2013. Analisis Efisiensi Teknis Usahatani Padi di Jawa Barat Indonesia. Agribusiness Journal 7(1) : 15-34

Yoko, B., Y. S., \& A. F. (2014). Analisis Efisiensi Usahatani Padi di Kabupaten Lampung Tengah. Jurnal Agribisnis Indonesia 2 (2) : 127-140 